\title{
Aberrant cytokine production from tenosynovium in dialysis associated amyloidosis
}

\author{
Nobuyuki Miyasaka, Kazuto Sato, Yuri Kitano, Megumu Higaki, Kusuki Nishioka, \\ Kazuo Ohta
}

Department of

Immunological Diseases,

Medical Research

Institute,

Tokyo Medical and

Dental University,

Tokyo, Japan

N Miyasaka

M Higaki

Institute of

Rheumatology,

Tokyo Women's

Medical College,

Tokyo, Japan

K Sato

K Nishioka

Institute of

Nephrology, Tokyo

Women's Medical

College, Tokyo,

Japan

Y Kitano

K Ohta

Correspondence to:

Dr Nobuyuki Miyasaka,

Department of

Immunological Diseases,

Medical Research

Institute, Tokyo Medical

and Dental University,

and Dental Unive

Bunkyo-ku, Tokyo,

Bunkyo-ku,

Accepted for publication

8 November 1991

\begin{abstract}
Culture supernatants of tenosynovial tissues from patients with carpal tunnel syndrome undergoing chronic haemodialysis contained interleukin (IL) 1-like and IL6-like activity. These culture supernatants also induced active proliferation of rheumatoid synovial cells. Immunohistochemical analysis of tenosynovial tissues showed the accumulation of mononuclear cells bearing CD14 and HLADR antigens adjacent to the deposition of amyloid protein ( $\beta_{2}$ microglobulin). These cells also reacted with antibodies to ILI and IL6 respectively. These data suggest that multiple cytokines, including ILL and IL6, produced from tenosynovial tissues in patients with dialysis associated amyloidosis might induce the proliferation of synovial cells that, together with deposition of amyloid protein, might cause carpal tunnel syndrome.
\end{abstract}

Carpal tunnel syndrome is often found in patients undergoing long term haemodialysis. ${ }^{1}$ There is a positive correlation between the incidence of carpal tunnel syndrome and the duration of haemodialysis. ${ }^{2}$ Patients who undergo haemodialysis for more than 15 years are always affected by carpal tunnel syndrome. ${ }^{3}$ Deposition of amyloid protein in the carpal tunnel area is believed to cause compression of the median nerve resulting in carpal tunnel syndrome, ${ }^{4}$ a clinical condition referred to as dialysis associated amyloidosis. The major component of amyloid protein in this situation was found by Gejyo et $a l^{5}$ to be $\beta_{2}$ microglobulin, a low molecular weight amyloidogenic protein (molecular weight 11.8 kilodaltons) ${ }^{6}$ that cannot be removed by conventional haemodialysis.

In addition to amyloid deposition, however, we found the proliferation of synovial cells in biopsy samples of tenosynovial tissues from the carpal tunnel area of patients undergoing long term haemodialysis and therefore reconsidered whether carpal tunnel syndrome is solely attributable to the local deposition of $\beta_{2}$ microglobulin. We report here the augmented production of cytokines with activities of interleukin (IL) 1 and IL6 from biopsy samples of tenosynovial tissues from the carpal tunnel area and speculate that cytokines produced in situ might be responsible for the proliferation in tenosynovial tissues which subsequently causes carpal tunnel syndrome. We also suggest that local accumulation of $\beta_{2}$ microglobulin might stimulate synovial cells to induce constitutive production of cytokines from tenosynovial tissues.

\section{Patients and methods}

PATIENTS

Fifteen patients with carpal tunnel syndrome undergoing long term haemodialysis (mean duration 10.4 years) were selected for the study (table 1). Informed consent was obtained from all patients. Surgical decompression of the median nerve was performed and biopsy samples of tenosynovial tissues were taken at the same time from the carpal tunnel area without complications. These samples were used for assays of cytokine activity and immunohistochemical staining. Tenosynovial tissues obtained from eight patients with trauma were used as controls.

\section{CULTURES}

Biopsy samples were processed as reported previously. ${ }^{7}$ Briefly, biopsy specimens were dissected into fragments $3 \mathrm{~mm}$ in diameter, washed extensively with RPMI 1640 (Gibco, Grand Island, NY, USA) and a fragment was plated into each well in 24 well culture plates (Sumitomo, Japan) as an organ culture with RPMI 1640 supplemented with $10 \%$ heat inactivated fetal calf serum (Gibco), $100 \mathrm{U} / \mathrm{ml}$ penicillin, $100 \mu \mathrm{g} / \mathrm{ml}$ streptomycin, and $10 \mathrm{mM}$ HEPES. Cultures for ILl and IL6 were performed as described in the following.

\section{MEASUREMENT OF ILI ACTIVITY}

Interleukin 1 activity was measured by a growth inhibition assay using the melanoma cell line 
A375.$^{89}$ Briefly, A375 cells were plated into 96 well flat bottom culture plates $\left(1 \times 10^{4} /\right.$ well $)$ in Eagle's minimal essential medium supplemented with $10 \%$ fetal calf serum with various dilutions of test samples or recombinant ILl $\beta$. After four days' incubation at $37^{\circ} \mathrm{C}, 0.5 \%$ neutral red was added to each well. Neutral red incorporated in viable cells was extracted with ethanol after two hours of culture. The absorbance of each well was measured at $540 \mathrm{~nm}$ by a multiscan spectrophotometer. One unit of growth inhibitory factor per millilitre represented the reciprocal of the dilution of samples causing $50 \%$ cytostasis or cytolysis after four days of culture, which is equivalent to the activity exerted by $50 \mathrm{pg} / \mathrm{ml}$ of recombinant IL $1 \beta$. In preliminary experiments, recombinant ILl $\alpha$ activity was blocked by antibodies to human ILl $\alpha$, and recombinant ILl $\beta$ activity was neutralised by antibodies to human ILI $\beta$. The specificity of the assay was further confirmed by using recombinant human tumour necrosis factor $\alpha$, IL2, and IL6. With this assay, 2-1000 $\mathrm{pg} / \mathrm{ml}$ of ILl was detectable. In addition, a thymocyte proliferation assay was used to confirm ILl activity. ${ }^{10}$ One ILl unit in this assay is defined as the half maximum response of thymocytes to recombinant human ILl $\beta$. An enzyme linked immunosorbent assay (ELISA) for ILl $\beta$ was also performed in some of the samples using a commercial kit (Ohtsuka Assay Co. Ltd, Japan). ${ }^{11}$

In part of the experiments using the A375 cell line, samples with known IL1-like activity were added to A375 cells with either polyclonal antibodies to human ILl $\alpha$ (1:400 dilution), antibodies to IL1 $\beta$ (1:400), or an equivalent dose of normal rabbit IgG to determine whether their ILl-like activity in the samples was neutralised by these antibodies. These antibodies have been described in detail elsewhere. ${ }^{11}$

In addition, part of the samples with increased ILl activity were preincubated for two hours at $37^{\circ} \mathrm{C}$ in the presence or absence of $5 \mu \mathrm{g}$ of polymyxin B (Pfizer, New York, NY, USA) to remove any lipopolysaccharide in the samples.

\section{MEASUREMENT OF IL6 ACTIVITY}

Interleukin 6 activity was determined with an Epstein-Barr virus transformed B cell line, SKW-C1 -4 , as described previously. ${ }^{12}$ Briefly, $1 \times 10^{4}$ cells $/ 200 \mu \mathrm{l} /$ well were cultured with test samples or recombinant IL6 for four days, and the concentration of IgM in the culture supernatants was determined by an ELISA. Interleukin 6 activity was also measured using the IL6 dependent murine hybridoma MH60.BSF2 cell clone. ${ }^{13}$ The growth of MH60.BSF2 cells was dependent on IL6; none of the other lymphokines examined (human ILl $\alpha$, ILl $\beta$, IL3, IL4, interferon $\gamma$, interferon $\alpha$, or granulocyte colony stimulating factor supported the growth of this clone. MH60.BSF2 cells $\left(1 \times 10^{4}\right.$ cells $/ 200 \mu \mathrm{l} /$ well) were cultured with various concentrations of test samples or recombinant IL6 for 48 hours, and DNA synthesis was measured by a spectrophotometric assay using 3-(4,5-dimethylthiazol-2-yl)-2,5-diphenyltetrazolium bromide. ${ }^{14}$ In some of the experiments,
MH60.BSF2 cells were cultured with the test sample together with the IgG fraction of antibodies to IL6 or preimmune rabbit serum to determine whether IL6-like activity was neutralised.

\section{ASSAY FOR SYNOVIAL CELL GROWTH PROMOTING} ACTIVITY

A source of synovial cells was derived from rheumatoid synovium as sufficient amounts of synovial cells were not obtained from normal synovium. The synovial tissue obtained by arthroscopic synovectomy from the knee joints of a patient with rheumatoid arthritis was minced, washed extensively with phosphate buffered saline (PBS), and treated with PBS plus $0 \cdot 25 \%$ trypsin for 40 minutes at $37^{\circ} \mathrm{C} .{ }^{15}$ The cells were washed three times with PBS and finally suspended in HAM F-12 medium (Gibco) supplemented with $10 \%$ fetal calf serum, $5 \times 10^{-5}$ M 2-mercaptoethanol, $100 \mathrm{U} / \mathrm{ml}$ penicillin, and $100 \mu \mathrm{g} / \mathrm{ml}$ streptomycin. The cells were incubated in culture flasks until confluence, then treated with $0.05 \%$ trypsin for five minutes at room temperature. Morphologically, most of these cells were fibroblast-like cells. After they were adjusted to $2 \times 10^{4}$ cells $/ \mathrm{ml}$ with $10 \%$ fetal calf serum-RPMI $1640,100 \mu \mathrm{l}$ of the cell suspension was plated in 96 well culture plates with various concentrations of test samples or recombinant ILl $\beta$ for 72 hours, and neutral red uptake was measured by the method described earlier.

\section{IMMUNOHISTOCHEMICAL ANALYSIS}

Immunohistochemical staining was performed as described previously. ${ }^{7}$ In brief, specimens embedded in OCT medium (Miles, Naperville, IL, USA) were frozen in liquid nitrogen and stored at $-70^{\circ} \mathrm{C}$. Frozen tissues were fixed with acetone and stained by monoclonal or polyclonal antibodies as described below. Antibodies to CD2, CD4, CD8, CD20, CD21 (reactive with $B$ cells), $I_{2}$ (reactive with HLA-DR antigens), $\mathrm{CD} 13$ (reactive with myelocytes, granulocytes, and monocytes), and CD14 (reactive with monocytes and macrophages) were all from Coulter Immunology (Hialeah, FL, USA). The tissue sections were incubated with a specific antibody or a control antibody of the same isotype. After rinsing, the sections were reacted with a serum sample containing biotinylated goat antimouse (IgG plus IgM) antibodies (Tago, Burlingame, CA, USA), followed by avidin-biotin complex (Vector Laboratories, Burlingame, CA, USA) and then the substrate, 3', 3'-diaminobenzidine. When rabbit antibodies to human IL1 $\beta$ (OCT204) or IL6 was used, the sections were reacted with the serum sample containing biotinylated goat antirabbit (IgG plus IgM) antibodies, followed by avidin-biotin complex.

\section{STATISTICAL ANALYSIS}

Statistical analysis was performed by Wilcoxon's rank sum test. 


\section{Results}

INTERLEUKIN 1-LIKE ACTIVITY IN THE CULTURE SUPERNATANTS FROM BIOPSY SAMPLES OF TENOSYNOVIAL TISSUES FROM PATIENTS WITH DIALYSIS ASSOCIATED AMYLOIDOSIS

Culture supernatants from tenosynovial tissues harvested on day 1 of culture strongly inhibited the growth of the A375 human melanoma cell line in a dose dependent manner (fig 1). The mean (SE) value was $44.8(11.9) \mathrm{U} / \mathrm{ml}$, suggesting that the culture supernatants contained IL1like activity (table 1). This activity was significantly increased compared with that in culture supernatants obtained from patients with trauma $(2.0(0.3) \mathrm{U} / \mathrm{ml} ; \mathrm{p}<0.01)$. The ILl-like factor was also produced by tenosynovial tissues cultured for 24 hours in medium with polymyxin $\mathrm{B}$, indicating that contamination by lipopolysaccharide is not responsible for the production of ILl-like factor. The ILl-like activity was greater on day 1 of culture than on day 4 or 7 . Furthermore, the ILl-like activity in the supernatants was significantly blocked by antibodies to IL $1 \beta$, but not by normal rabbit IgG, indicating that most of the ILl-like activity could be ascribed to the IL1 $\beta$ molecule (fig 2). As the amounts of tenosynovial tissues obtained were

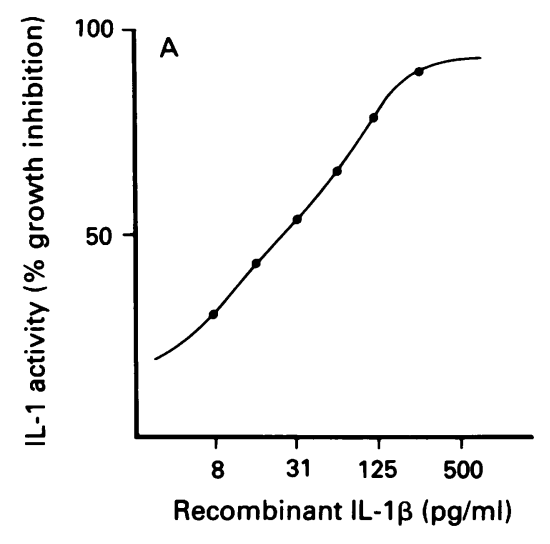

Figure 1 Interleukin l-like activity in culture supernatants of tenosynovial tissues from lon term haemodialysis patients with carpal tunnel syndrome. A375 cells were cultured with various dilutions of either $(A)$ recombinant ILIB or $(B)$ four representative culture supernatants for four days as described under methods. small, not enough sample was available for further testing. The ILl-like activity was further confirmed, however, by thymocyte

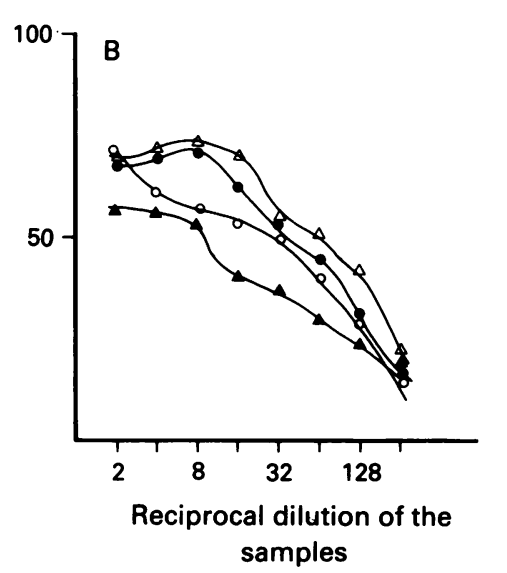

Table 2 Detection of interleukin I (ILI) in culture supernatants from tenosynovial tissues by various assays

\begin{tabular}{llll}
\hline \multicolumn{5}{c}{ ILl activity } & \\
\cline { 2 - 4 } & $\begin{array}{l}\text { GIF } \\
(U / m l)^{*}\end{array}$ & $\begin{array}{l}\text { LAF } \\
(U / m l) t\end{array}$ & $\begin{array}{l}\text { ELISA } \\
(p g / m l) \ddagger\end{array}$ \\
\hline Sample 1 & 42 & $6 \cdot 1$ & 82 \\
Sample 2 & 12 & $2 \cdot 0$ & 15
\end{tabular}

*GIF assay using A375 cell line.

†LAF assay using murine thymocytes.

†Enzyme linked immunosorbent assay for ILl.

Table 3 Interleukin (IL) 6 activity in a culture supernatan from tenosynovial tissue and its inhibition by polyclonal antibodies to IL6

\begin{tabular}{lll}
\hline Sample & Antibody to IL6 & Absorbancet \\
\hline Culture supernatant & - & $0 \cdot 140$ \\
$\quad(1: 200)$ & + & $0 \cdot 028$ \\
Culture supernatant & - & $0 \cdot 075$ \\
(1:800) & + & $0 \cdot 022$ \\
No culture supernatant & - & $0 \cdot 015$
\end{tabular}

${ }^{*}$ Final concentration of antibody $12.5 \mathrm{~g} / \mathrm{ml}$

†Absorbance of a culture supernatant of the SKW-Cl-4 cell line †Absorbance of a culture super
cultured with each sample.

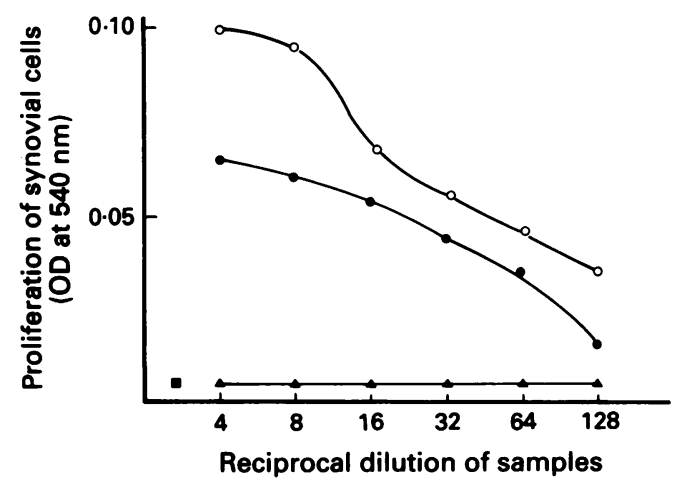

Figure 2 Neutralisation of ILI activity in culture supernatants from tenosynovial tissues by antibodies to ILI. A375 cells were cultured with a culture supernatant from $a$ tenosynovial tissue sample (final concentration

( $1.5 \% \mathrm{vol} / \mathrm{vol}$ ) together with antibodies to ILI or preimmune rabbit IgG for four days. Bars indicate standard errors of the experiment. A representative result is shown in repeated experiments.

Figure 3 Rheumatoid synovial cells $\left(1 \times 10^{4} /\right.$ well $)$ were cultured with various dilutions of samples: $(\bigcirc)$ a culture supernatant of a tenosynovial tissue (patient No I), (O)

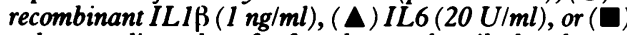
culture medium alone for four days as described under methods. The results of a representative experiment are methods. 
SYNOVIAL CELL GROWTH PROMOTING ACTIVITY IN CULTURE SUPERNATANTS FROM TENOSYNOVIAL TISSUES

Synovial cells obtained from rheumatoid synovial tissue as described under methods were cultured for approximately two weeks. These cultured synovial cells were plated $\left(2 \times 10^{4}\right.$ cells/well) and incubated with various concentrations of culture supernatants from tenosynovial tissues or recombinant IL $1 \beta$ for 72 hours at $37^{\circ} \mathrm{C}$. Figure 3 shows that these supernatants promoted the growth of synovial cells in a dose dependent manner; this capacity was more potent than that obtained with $1 \mathrm{ng} / \mathrm{ml}$ of recombinant $\mathrm{ILl} \beta$. In addition, this activity was also blocked by antibodies to ILl $\beta$.

\section{IMMUNOHISTOCHEMICAL STAINING OF} TENOSYNOVIAL TISSUES

Haematoxylin-eosin staining of the tenosynovial tissues obtained from haemodialysis patients with carpal tunnel syndrome showed prominent

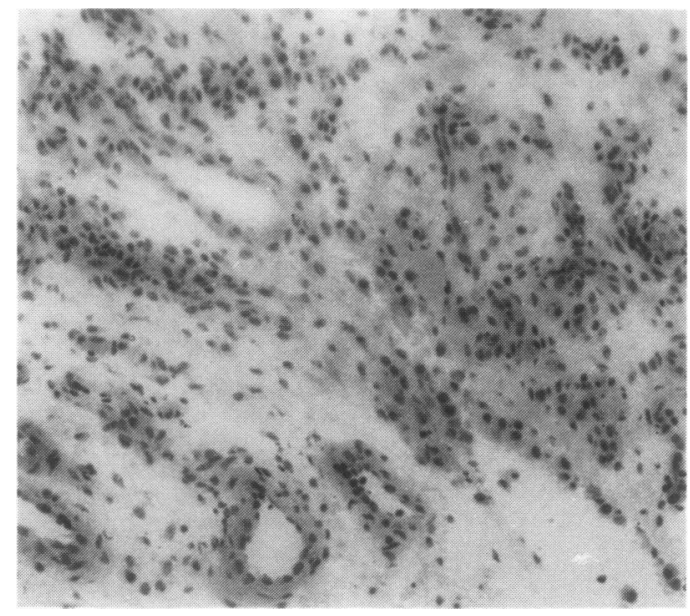

Figure 4 Haematoxylin-eosin stain of the tenosynovial tissue obtained from a patient with carpal tunnel syndrome undergoing haemodialysis shows proliferation of synovial cells.

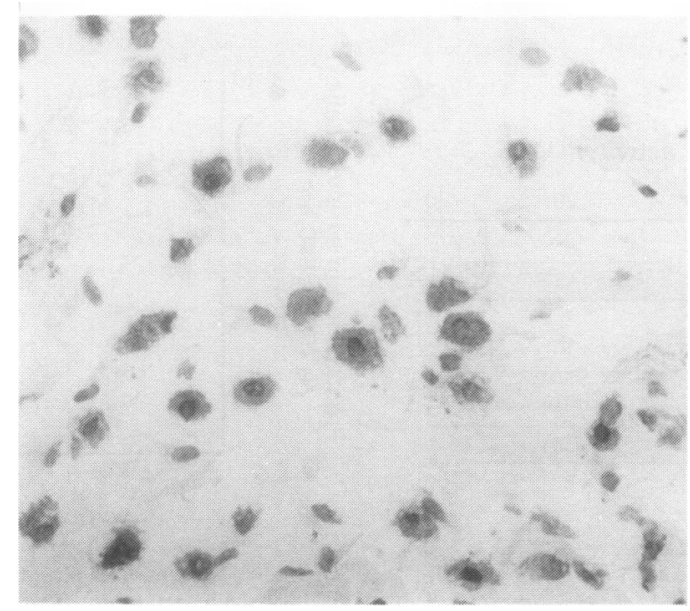

Figure 5 Immunohistochemical analysis of synovial cells in tenosynovial tissues. Most of the cells showed cytoplasmic staining with monoclonal antibodies to CDI4.

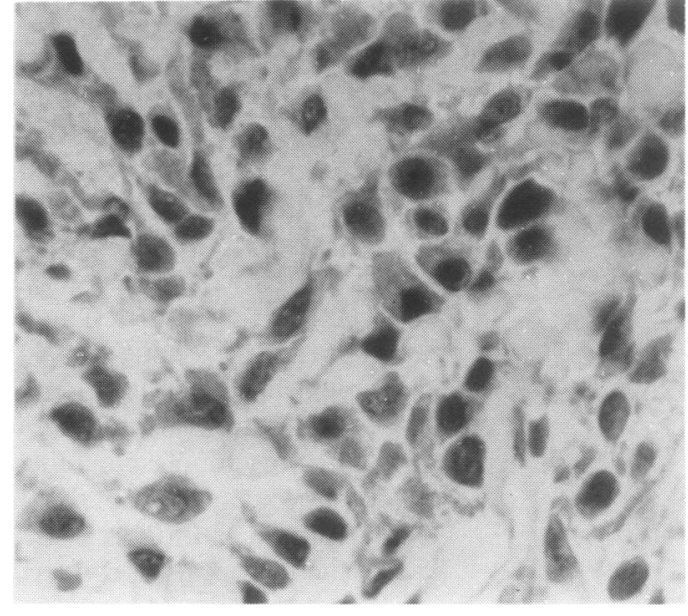

Figure 6 Immunohistochemical analysis of ILI producing cells. Synovial cells showed cytoplasmic staining with polyclonal antibodies to ILI.

proliferation of synovial cells and scattered deposition of amorphous materials (fig 4). These amorphous materials were positive for Congo red with a typical green birefringence observed under a polarising microscope.

None of the cells infiltrating the tenosynovial tissues reacted with antibodies to $\mathrm{T}$ cells (CD2) or B cells (CD20). Most proliferating cells were positive for CD14 (fig 5) and approximately one third of CD14 positive cells expressed CD13 on their surfaces. They also had HLA-DR antigens on their surfaces. These data suggest that the proliferating synovial cells could have originated as macrophages. Moreover, these cells reacted strongly with polyclonal antibodies to human IL1 $\beta$ (fig 6) and antibodies to human IL6. Preincubation of specific antibodies with the corresponding recombinant cytokines completely abolished these stainings (data not shown). These data indicate that there might be ILl and IL6 producing synovial cells in tenosynovial tissues.

\section{Discussion}

Carpal tunnel syndrome is now recognised to be one of the major complications of long term haemodialysis, and a significant correlation has been found between carpal tunnel syndrome and the duration of haemodialysis. ${ }^{2}$ The deposition of amorphous materials that have a high affinity to Congo red and are sensitive to potassium permanganate treatment is invariably found in the tenosynovial tissues of these patients. This amyloid protein appears to be intact $\beta_{2}$ microglobulin, ${ }^{16}$ a low molecular weight protein associated with major histocompatibility complex class I antigens. The deposition of $\beta_{2}$ microglobulin is itself believed to induce compression of the median nerve, resulting in carpal tunnel syndrome. Marked proliferation of synovial cells is found in the tenosynovial tissues of these patients, however, and can also be responsible for compression of the median nerve.

In this study, we showed a potent IL1-like activity in culture supernatants of biopsy 
samples of tenosynovial tissues from patients with carpal tunnel syndrome undergoing long term haemodialysis. This organ culture system overcomes the difficulties of obtaining enough cells from the limited amount of tissue for functional studies. The cytokine activity detected here can be ascribed to IL $1 \beta$, as most of it was neutralised by the antibody against human IL1 $\beta$. In addition, the IL1-like activity was confirmed by thymocyte proliferation assay and an ELISA in the sample tested. Interleukin 1 produced in the culture supernatants is speculated to be constitutively secreted from synovial cells and not to be induced during the culture, as immunohistochemical analysis using antibodies to ILl showed cytoplasmic staining corresponding to synovial cells. In addition, polymyxin B did not alter the IL1 activity in the culture supernatants. It has been shown that IL $1 \beta$ is secreted, whereas ILl $\alpha$ remains associated with cells. ${ }^{17}$ It is therefore necessary to measure the amount of intracellular ILl to clarify this point further. Interleukin 6 activity was also found in these culture supernatants using the SKW-Cl-4 and MH60.BSF2 cell lines. This activity was also blocked by a specific antibody against IL6. Antibodies to IL6 reacted with synovial cells in immunohistochemical staining suggesting that these are the IL6 producing cells in tenosynovial tissues. Moreover, these culture supernatants induced active proliferation of rheumatoid synovial cells in vitro. The experiment performed simultaneously showed that ILl, but not IL6, is capable of inducing proliferation of synovial cells in vitro. These data suggest that cytokines, including ILl, produced in situ might contribute to the proliferation of synovial cells, resulting in entrapment of the median nerve in the carpal tunnel.

The so called 'interleukin hypothesis' has been proposed to explain acute and chronic complications observed in patients undergoing long term haemodialysis. ${ }^{18}$ Among the interleukins, ILl is thought to play a central part in the pathogenetic changes seen in haemodialysis patients. ${ }^{19}$ Symptoms such as fever, lassitude, wasting, sleepiness, and possibly hypotension can be ascribed to the acute production of ILl in vivo. The significance of the chronic production of ILl in long term haemodialysis patients remains to be clarified. Local production of ILl can affect many complications seen in haemodialysis, however, including destructive arthropathy and carpal tunnel syndrome. We have already reported augmented ILl production in the synovium of patients with rheumatoid arthritis. ${ }^{7}$ Interleukin 1 induces the production of prostaglandins and collagenase from synovial cells. ${ }^{20}$ Interleukin 1 also promotes the growth of fibroblasts, ${ }^{21}$ and activates osteoclasts. ${ }^{22}$ Interleukin 1 upregulates the production of $\mathrm{ILl}^{23}$ and triggers IL6 production. ${ }^{24}$ Thus cytokines constitutively produced in tenosynovial tissue could evoke destructive arthropathy on the one hand and synovial proliferation which causes carpal tunnel syndrome in long term haemodialysis patients on the other. In this respect, we previously showed that cloned rheumatoid synovial cells spontaneously liberate both $\mathrm{ILI}^{15}$ and IL6 ${ }^{25}$ in culture. Cells that belong to the macrophage lineage are known to produce IL1 and IL6 in response to the correct stimulifor example, silica and lipopolysaccharide. ${ }^{26}$ The stimulus that produces IL1 and IL6 from proliferating synovial cells in this instance is not known at present. Multiple mechanisms including contamination of endotoxin and complement activation may contribute to the constitutive production of ILl in long term haemodialysis patients. It is interesting to speculate, however, that amyloid protein deposited locally in tenosynovial tissue might activate synovial cells. Further studies will be necessary to clarify this point.

This is the first study to examine the relationship between in vitro cytokine production and the pathogenesis of carpal tunnel syndrome in haemodialysis associated amyloidosis.

This work was partly supported by a Grant-in-Aid from the Ministry of Health and Welfare, Japan. We are grateful to D Yoshikatsu Hirai of Otsuka Pharmaceutical Company for kindly supplying the A375 cell line and the antibodies to IL1 and to Dr Toshio Hirano and Dr Tadamitsu Kishimoto of the Institute for Mon Molecular and Cellular Biology, Osaka University, for providing the IL6 dependent cell lines. We also thank Mr Kazumasa Ikeda of Japan Scientific Instrument Company for monoclonal antibodies, and Miss Hiroko Inoue of Mitsubishi Yuka BCL Co. Lt and Mrs Junko Hashimoto for their superb technical assistance Antibodies to IL6 (raised by immunising rabbits with human recombinant IL6)
Ajinmoto Co. Ltd.

Warren D J, Otieno L S. Carpal tunnel syndrome in patients on intermittent hemodialysis. Postgrad Med f 1975; 51 : on intern

2 Schwarz A, Keller F, Seyfert S, Poll W, Molzahn M, Distler A. Carpal tunnel syndrome: a major complication in longterm hemodialysis patients. Clin Nephrol 1984; 22: 133-7.

3 Bardin T, Kuntz D, Zingraff J, Voisin M, Zelmar A Lansaman J. Synovial amyloidosis in patients undergoin long-term hemodialysis. Arthritis Rheum 1985; 28: 1052-8

4 Bardin T, Zingraff J, Noel L, et al. Hemodialysis-associated amyloidosis and beta- 2 microglobulin. Clinical and immunohistochemical study. Am f Med 1987; 83: 419-24.

5 Gejyo F, Yamada T, Odani S, et al. A new form of amyloid protein associated with chronic hemodialysis was identified as microglobulin. Biochem Biophys Res Commun 1985; 129: as microg.

6 Gorevic P D, Casey T T, Stone W J, DiRaimondo C R, Prell F C, Frangione B. Beta-2 microglobulin is an amyloidogenic protein in man. $\mathcal{f}$ Clin Invest 1985; 76: 2425-9.

7 Miyasaka N, Sato K, Goto M, et al. Augmented interleukin-1 production and HLA-DR expression in the synovium of rheumatoid arthritis patients. Possible involvement in join destruction. Arthritis Rheum 1988; 31: 480-6.

8 Nakai S, Mizuno K, Kaneta M, Hirai Y. A simple, sensitive bioassay for the detection of interleukin-1 using human melanoma A375 cell line. Biochem Biophys Res Commun 1988; 154: 1189-96.

9 Lachman L B, Dinarello C A, Leansa N D, Fidler I J. Natural and recombinant IL-1 is cytotoxic for human melanoma cells. F Immunol 1986; 136: 3098-102.

10 Lachman L B, Hacker M P, Blyden G T, Handschumacher R E. Preparations of lymphocyte-activating factor from continuous murine macrophage cell lines. Cell Immunol continuous murine

11 Tanaka $\mathrm{K}$, Ishikawa $\mathrm{E}$, Ohmoto $\mathrm{Y}$, Hirai $\mathrm{Y}$. In vitro production of human interleukin 1 and interleukin 1 by peripheral blood mononuclear cells examined by sensitive sandwich enzyme immunoassay. Eur $\mathcal{F}$ Immunol 1987; 17 1527-30.

12 Hirano T, Taga T, Nakano $\mathrm{N}$, et al. Purification to homogeneity and characterization of human $\mathrm{B}$ cell differen tiation factor (BCDF or BSFp-2). Proc Natl Acad Sci USA 1985; 82: 5490-4.

13 Matsuda T, Hirano T, Kishimoto T. Establishment of interleukin-6/B cell stimulatory factor 2 (BSF-2)-dependen cell line and preparation of anti-IL-6/BSF-2 monoclona antibodies. Eur F Immunol 1988; 18: 951-4.

14 Mosman T. Rapid colorimetric assay for cellular growth and survival: application to proliferation and cytotoxicity assay. f Immunol Methods 1983; 65: 55-63.

15 Goto M, Sasano M, Yamanaka H, et al. Spontaneous production of an interleukin-1-like factor by cloned production of an interleukin-1-like factor by cloned
rheumatoid synovial cells in long-term culture. $\boldsymbol{f}$ Clin Invest 1987; 80: 786-96.

16 Gejyo F, Odani S, Yamada T, et al. Beta 2-microglobulin: a 
new form of amyloid protein associated with chronic hemodialysis. Kidney Int 1986; 30: 385-90.

17 Conlon P J, Grabstein K H, Alpert A, Prickett K S, Hopp T P, Gillis S. Localization of human mononuclear cell interleukin 1. f Immunol 1987; 139: 98-102.

18 Dinarello $C$ A, Koch $K$ M, Shaldon S. The interleukin Din hypothesis. Interleukin-1 and its relevance in patients treated with hemodialysis. Kidney Int 1988; 33 (suppl 24): S21-6.

19 Bingel M, Lonnemann G, Shaldon S, Koch K M, Dinarello $\mathrm{CA}$. Human interleukin-1 production during hemodialysis. Nephron 1986; 43: 161-3.

20 Dayer J M, de Rochemonteix B, Burrus B, Demczuk S Dinarello C A. Human recombinant interleukin 1 stimulates collagenase and prostaglandin $\mathrm{E}$ production by human synovial cells. F Clin Invest 1986; 77: 645-8.

21 Schmidt J A, Mizel S B, Cohen D, Green I. Interleukin 1: a potential regulator of fibroblast proliferation. 7 Immuno 1982; 128: 2177-82.
22 Dewhirst F E, Stashenko P P, Mole J E, Tsurumachi T. Purification and partial sequence of human osteoclast-
activating factor: identity with interleukin $1 /$. F Immunol 1985; 135: 2562-8.

23 Dinarello C A, Ikejima T, Warner S J C, et al. Interleukin I induces interleukin 1. I. Induction of circulating interinduces interleukin 1 . I. Induction of circulating inter-
leukin 1 in rabbits in vivo and human mononuclear cells in leukin 1 in rabbits in vivo and human
vitro. $f$ Immunol 1987; 139: 1902-10.

24 Content J, De Wit L, Poupart P, Opdenakker G, Van Damme J, Billiau A. Induction of a 26-kDa-protein mRNA in human cells treated with an interleukin-1-related, leukocyte-derived factor. Eur f Biochem 1985; 152: 253-7.

25 Miyasaka $\mathrm{N}$, Sato $\mathrm{K}$, Hashimoto $\mathrm{J}$, et al. Constitutive production of interleukin 6/B cell stimulatory factor- 2 from inflammatory synovium. Clin Immunol Immunopathol 1989, 52: $238-47$.

26 Kishimoto T, Hirano T. Molecular regulation of B lymphocyte response. Ann Rev Immunol 1988; 6: 485-512. 